\section{Seedling Emergence, Growth, and Mineral Nutrition of Ornamental Chile Peppers Irrigated with Saline Water}

\author{
Genhua Niu $^{3}$ \\ Texas A\&M AgriLife Research Center at El Paso, 1380 A\&M Circle, \\ El Paso, TX 79927 \\ Pedro Osuna ${ }^{1}$ \\ Universidad Autónoma de Cd. Juárez, Chihuahua, México \\ Youping Sun and Denise S. Rodriguez ${ }^{2}$ \\ Texas A\&M AgriLife Research Center at El Paso, 1380 A\&M Circle, \\ El Paso, TX 79927
}

Additional index words. growth stage, landscape irrigation, mineral nutrition, salt tolerance, seedling emergence

\begin{abstract}
Ornamental chile peppers are popular bedding plants. As high-quality water supply becomes limited in many parts of the world, alternative waters such as municipal reclaimed water is encouraged to be used for landscape irrigation. The purpose of this study was to assess the relative salt tolerance of 10 cultivars of ornamental chile peppers by irrigating the mature plants with saline solutions and germinating seeds in saline substrate in a greenhouse. In the mature plant salt tolerance experiment, plants were irrigated with nutrient solution (no addition of salts, control) or saline solution at electrical conductance (EC) of $4.1 \mathrm{dS} \cdot \mathrm{m}^{-1}$ or $8.1 \mathrm{dS} \cdot \mathrm{m}^{-1}$ for 8 weeks. Plants in the EC of $4.1 \mathrm{dS} \cdot \mathrm{m}^{-1}$ treatment did not have any foliar salt damage regardless of cultivar. At $\mathrm{EC}$ of $8.1 \mathrm{dS} \cdot \mathrm{m}^{-1}$, 'NuMex Memorial Day' had the most severe foliar salt damage, whereas 'NuMex April Fool's Day', 'NuMex Cinco de Mayo', 'NuMex Thanksgiving', and 'NuMex Twilight' had little or no foliar damage. Shoot dry weight (DW) reduction at EC of $8.1 \mathrm{dS} \cdot \mathrm{m}^{-1}$ compared with control was smallest in 'NuMex Thanksgiving' (15\%), whereas 'NuMex Memorial Day' had the greatest reduction of $74 \%$ followed by 'NuMex Christmas' of $61 \%$. The highest shoot DW reduction in 'NuMex Memorial Day' coincided with lowest visual score, indicating that this cultivar was the least tolerant to salinity. The leaf $\mathrm{Na}^{+}$and $\mathrm{Cl}^{-}$concentrations increased dramatically with increasing EC of the irrigation water in all cultivars. The highest $\mathrm{Na}^{+}$concentration of $10.9 \mathrm{mg} \cdot \mathrm{g}^{-1} \mathrm{DW}$ at $\mathrm{EC}$ of $8.1 \mathrm{dS} \cdot \mathrm{m}^{-1}$ was observed in 'NuMex Christmas'. The highest $\mathrm{Cl}^{-}$concentration at $\mathrm{EC}$ of $8.1 \mathrm{dS} \cdot \mathrm{m}^{-1}$ was found in 'NuMex Memorial Day' with $64.8 \mathrm{mg} \cdot \mathrm{g}^{-1} \mathrm{DW}$, which was four times higher than the control. In the seedling emergence experiment, seeds of the 10 cultivars were germinated in substrate either moistened with reverse osmosis water $(E C \approx 0)$ or saline solution at $E C$ of $17.1 \mathrm{dS} \cdot \mathrm{m}^{-1}$. 'NuMex Christmas' and 'NuMex Memorial Day' had the lowest relative seedling emergence index, indicating that these two cultivars were the least tolerant to salinity during the seedling emergence stage. 'NuMex Thanksgiving' and 'NuMex Cinco de Mayo' had the highest relative seedling emergence index. Combining the results from both experiments, we concluded that 'NuMex Cinco de Mayo' and 'NuMex Thanksgiving' were the most tolerant cultivars, whereas 'NuMex Christmas' and 'NuMex Memorial Day' were the least tolerant ones.
\end{abstract}

\footnotetext{
Received for publication 6 Sept. 2012. Accepted for publication 3 Oct. 2012.

We gratefully acknowledge the financial support from Cooperative State Research, Education and Extension Service, U.S. Department of Agriculture under Agreement No. 2005-34461-15661. We also thank The Chile Pepper Institute of New Mexico State University for donating seeds.

${ }^{1}$ Visiting professor for sabbatical financed by UACJ and CONACYT, Mexico.

${ }^{2}$ Current address: Horticulture Agent at El Paso County Extension, Texas A\&M AgriLife Extension, E1 Paso, TX 79927.

${ }^{3}$ To whom reprint requests should be addressed; e-mail gniu@ag.tamu.edu.
}

Soil salinization is a global concern, especially in arid and semiarid regions with large and growing populations. It is becoming even more intense because high-quality irrigation water is limited and alternative water sources such as municipal reclaimed water are encouraged to be used for irrigating landscapes in some areas in the southwestern United States and northern Mexico. The irrigation of croplands with alternative waters has resulted in the accumulation of salts in soil and groundwater (Rozema and Flowers, 2008). The degree of soil salinization depends on the quality of irrigation water, soil property, fertilizer application, and rainfall because these factors influence the soil moisture content, cation exchange capacity, and transportation of water.

Salinity influences plant growth and development in all stages, although the degree of the negative salinity effect may be growth stage-dependent. For most crops, plants are generally more tolerant during germination but become more sensitive during emergence and early seedling growth stages (Maas, 1986; Rhoades, 1999). Once established, plants generally become increasingly tolerant during later growth stages. High salinity also induces a series of metabolic dysfunctions in plants, including absorption of excessive minerals, nutrient imbalance, and inhibition of photosynthesis (Azza Mazher et al., 2007; Marschner, 2002; Munns and Tester, 2008). The degree of the negative effect of salinity on plant growth and physiological processes depends on salinity level and length of exposure. The actual response of a plant to salinity is often affected by climate conditions, type of substrate or soil, and irrigation management in addition to growth or developmental stage.

Ornamental chile peppers (Capsicum annuum) are popular bedding plants and containerized plants resulting from their compact growth habit and numerous fruits that spread over the top of the plant and attractive foliage (Coon et al., 2008). The indeterminate growth habit produces fruits in all stages of development and provides an elegant blend of colors throughout the summer and fall (Stommel and Bosland, 2005). For example, the chile fruit starts green and then changes from ivory to red with bulletshaped pods for 'NuMex Valentine's Day', from ivory to orange with more rounded pod for 'NuMex St. Patrick's Day', and from ivory to lemon yellow with a round pod for 'NuMex Memorial Day'. However, information on the response of ornamental chile peppers to irrigation water with elevated salts is limited. Recent studies have showed that ornamental chile pepper 'Black Pearl' and 'Calico' were moderately salt-tolerant and may be irrigated with saline water up to $4.0 \mathrm{dS} \cdot \mathrm{m}^{-1}$ with little reduction in aesthetical appearance (Niu et al., 2010a). Also, a large variation in salt tolerance exists among chile pepper cultivars (Niu, 2012; Niu et al., $2010 \mathrm{~b}, 2010 \mathrm{c}$ ). The purpose of this study was to determine the relative salt tolerance of 10 cultivars of ornamental chile peppers based on seedling emergence, visual quality, growth, and physiological responses when germinated and irrigated with saline solution at elevated salinity levels.

\section{Materials and Methods}

Salt tolerance of mature plant (Expt. 1)

Plant materials and culture. Seeds of 10 cultivars of ornamental chile peppers ('NuMex April Fool's Day', 'NuMex Christmas', 'NuMex Cinco de Mayo', 'NuMex Easter', 'NuMex Halloween', 'NuMex Memorial Day', 'NuMex St. Patrick's Day', 'NuMex Thanksgiving', 'NuMex Twilight', 'NuMex 
Valentine's Day') were sown on 2 June 2011 in plug cells filled with Redi-earth Plug \& Seedling Mix (SunGro Hort., Bellevue, WA) and covered with $0.64 \mathrm{~cm}$ coarse vermiculite. Six weeks after sowing, seedlings were transplanted to 1.8-L round plastic pots filled with Sunshine Mix No. 4 (SunGro Hort.). The temperatures in the greenhouse during the experimental period were at $33.3 \pm 2.6{ }^{\circ} \mathrm{C}$ (mean \pm SD) during the day and $25.6 \pm 1.6^{\circ} \mathrm{C}$ at night. The daily light integral (photosynthetically active radiation) was measured at $18.6 \pm$ $3.0 \mathrm{~mol} \cdot \mathrm{m}^{-2} \cdot \mathrm{d}^{-1}$.

Treatments. Saline solutions at EC of 1.3 (control, no addition of salts), 4.1, and $8.1 \mathrm{dS} \cdot \mathrm{m}^{-1}$ were created by adding calculated amounts of sodium chloride $(\mathrm{NaCl})$ and calcium chloride $\left(\mathrm{CaCl}_{2}\right)$ at 2:1 (molar ratio) to a nutrient solution. The nutrient solution was made by adding $0.72 \mathrm{~g} \cdot \mathrm{L}^{-1}$ of $15 \mathrm{~N}-2.2 \mathrm{P}-$ 12.4K (Peters Excel 15-5-15; Scotts-Sierra Horticultural Product Co., Marysville, $\mathrm{OH}$ ) to tap water. Plants were grown in a greenhouse and irrigated with the nutrient solution before the start of treatment whenever the substrate surface became dry. The EC of tap water was $0.8 \mathrm{dS} \cdot \mathrm{m}^{-1}$ and the major ions in the tap water were $\mathrm{Na}^{+}, \mathrm{Ca}^{2+}, \mathrm{Mg}^{2+}, \mathrm{Cl}^{-}$, and $\mathrm{SO}_{4}{ }^{2-}$ at $184,52.0,7.5,223.6$, and $105.6 \mathrm{mg} \cdot \mathrm{L}^{-1}$, respectively. Saline solution irrigation (treatment) was initiated on 15 July and ended on 9 Sept. when plants were established in the pots and were about to flower in some cultivars. Irrigation frequency was determined based on cultivar (biomass), treatment, and climatic conditions to avoid overwatering and water stress. To prevent salt accumulation in the root zone, leachate was monitored periodically. Plants were irrigated with nutrient solution whenever the leachate EC was higher than the treatment EC.

Measurements. Experiment was ended $55 \mathrm{~d}$ after treatment. On termination, visual foliar salt damage (leaf edge burn, necrosis, and discoloration) was rated by giving a score to every plant from 0 to 5 , where $0=$ dead; $1=$ over $90 \%$ foliar damage; $2=$ moderate $(50 \%$ to $90 \%$ ) foliar damage; 3 = slight (less than $50 \%$ ) foliar damage; 4 = good quality with minimal foliar damage; and $5=$ excellent without any foliar damage.

Leaf osmotic potential $\left(\psi_{\mathrm{s}}\right)$ was measured according to Niu and Rodriguez (2006). Five plants were sampled per treatment per cultivar. Specifically, leaves were sampled from the middle section of the shoots in the early morning at the end of the experiment, sealed in a plastic bag, and immediately stored in a freezer at $-20{ }^{\circ} \mathrm{C}$ until analysis. Frozen leaves were thawed in the plastic bag at room temperature before sap was pressed out with a Markhart leaf press (LP-27; Wescor, Logan, UT) and analyzed using a vapor pressure Osmometer (Vapro Model 5520; Wescor).

Shoots were severed at the substrate surface at the end of the experiment. Leaves, stems, and fruits were separated, and their DWs were determined after being ovendried at $70{ }^{\circ} \mathrm{C}$ until a constant weight was reached. To compare the effect of salt stress on the reduction of growth (DW), a relative value to the control treatment was calculated for each plant in the salt treatments for each genotype. That is, relative shoot DW was calculated as:

\section{Relative Shoot DW =}

$$
\frac{\text { Shoot DW in salt treatment }}{\text { Averaged shoot DW in control }} \times 100 \%
$$

Similarly, relative leaf DW, relative stem DW, and relative fruit DW were calculated. These relative values were used for comparison among genotypes in data analysis mentioned below.

Mineral analysis. Five leaf samples per treatment per cultivar were randomly collected for mineral analysis. Dry tissues were ground to pass a 40-mesh screen with a stainless Wiley mill (Thomas Scientific, Swedesboro, NJ). Powder samples were digested with sulfuric acid for determining cations $\left(\mathrm{Na}^{+}, \mathrm{K}^{+}, \mathrm{Ca}^{2+}\right.$, and $\mathrm{Mg}^{2+}$ ) and extracted with $2 \%$ acetic acid for determining anions $\left(\mathrm{Cl}^{-}, \mathrm{NO}_{3}{ }^{-}, \mathrm{PO}_{4}^{-}\right.$, and $\mathrm{SO}_{4}^{-}$) using methods described in Gavlak et al. (1994). Cations $\mathrm{Na}^{+}, \mathrm{K}^{+}, \mathrm{Ca}^{2+}$, and $\mathrm{Mg}^{2+}$ concentrations were determined by inductively coupled plasma spectroscopy (Helmke and Sparks, 1996) and anions $\left(\mathrm{Cl}^{-}, \mathrm{NO}_{3}{ }^{-}, \mathrm{PO}_{4}^{-}\right.$, and $\mathrm{SO}_{4}^{-}$) were determined by the ion chromatography (Tabatabai and Frankenberger, 1996).

Statistical analysis. The experiment was a split-plot design with salinity of irrigation water as the main plot and cultivars as subplots with 10 replications. All data were analyzed by a two-way analysis of variance (ANOVA) using PROC GLM. Visual scores were analyzed by PROC NPAR1WAY, which was designed for non-parametric tests. To determine the differences among salinity levels on plant growth, Student-Newman-Keuls multiple comparisons were performed. All statistical analyses were performed using SAS software (Version 9.1.3; SAS Institute Inc., Cary, NC).

\section{Seedling emergence of ornamental chile peppers (Expt. 2)}

To determine whether the relative salt tolerance among the 10 cultivars was growth stage-dependent, a seedling emergence test was carried out. Square plastic pots $(13.34 \times$ $13.34 \times 5.87 \mathrm{~cm})$ were filled with a potting mix (Sunshine Mix No. 4; SunGro Hort.) and saturated with $250 \mathrm{~mL}$ of reverse osmosis (RO) water (control) or saline solution (salt treatment). Saline solution was prepared by dissolving the calculated amounts of $\mathrm{NaCl}$ and $\mathrm{CaCl}_{2}$ salts at $2: 1 \mathrm{M}$ ratio into $\mathrm{RO}$ water. The EC of the saline solution was $17.1 \mathrm{dS} \cdot \mathrm{m}^{-1}$. Seeds of 10 ornamental chile pepper cultivars were sown into the square pots on 26 Oct. 2011. The experiment followed a completely randomized design with three replications, 20 seeds per treatment per cultivar. Pots were misted with tap water whenever substrate surface started to dry to prevent water stress. Emergence was counted daily as soon as first emergence appeared for 5 weeks. A seedling was considered emerged when the hypocotyls hook was visible above the surface. The greenhouse environment was maintained at average day temperature at $24.3{ }^{\circ} \mathrm{C}$, night temperature at $18.0{ }^{\circ} \mathrm{C}$, and average daily relative humidity at $31.4 \%$.

Emergence percent (EP) was calculated as:

$\mathrm{EP}(\%)=$

Number of emerged seedlings

$\overline{\text { Total number of seeds per pot }}$

$\times 100 \%$

A relative EP was calculated for each cultivar in the salt treatment as:

Relative $\operatorname{EP}(\%)=$

$$
\frac{\text { EP in salt treatment }}{\text { Averaged EP in control }} \times 100 \%
$$

In addition to emergence percentage, emergence index $(\mathrm{EI})$ was calculated as $\mathrm{EI}=$ $\mathrm{EP}_{1} / \mathrm{T}_{1}+\mathrm{EP}_{2} / \mathrm{T}_{2}+\ldots+\mathrm{EP}_{35} / \mathrm{T}_{35}$, where $\mathrm{EP}_{1}$, $\mathrm{EP}_{2}, \ldots, \mathrm{EP}_{35}$ and $\mathrm{T}_{1}, \mathrm{~T}_{2}, \ldots, \mathrm{T}_{35}$ are the emergence percentages and days after sowing at the first, second, ..., and 35th day (experiment lasted $35 \mathrm{~d}$ ). Similar to relative $\mathrm{EP}$, relative EI was calculated as:

Relative $\mathrm{EI}(\%)=$

$$
\frac{\text { EI in salt treatment }}{\text { Averaged EI in control }} \times 100 \%
$$

Relative EP and relative EI were used in data analysis. Two-way ANOVA was used to analyze the effect of salinity and cultivar on relative emergence percentage and index. When main effects were significant, means were separated by Student-Newman-Keuls' multiple comparison at $P=0.05$.

\section{Results and Discussion}

Plant visual quality, osmotic potential, and shoot growth. The plants irrigated with nutrient solution at EC of 1.3 (control) and saline solutions at EC of $4.1 \mathrm{dS} \cdot \mathrm{m}^{-1}$ did not have any foliar damage, regardless of cultivar. However, minor foliar damage was observed on some plants in many cultivars when irrigated with saline solution at EC of $8.1 \mathrm{dS} \cdot \mathrm{m}^{-1}$ (Table 1). 'NuMex Memorial Day' had the most severe foliar damage with an average score of 2.5 (Fig. 1). 'NuMex April Fool's Day', 'NuMex Cinco de Mayo', 'NuMex Thanksgiving', and 'NuMex Twilight' had little or no foliar damage. 'NuMex Christmas' also had a relatively low visual score of 4.7. In a previous study, Niu et al. (2010a) found that three ornamental chile cultivars (Black Pearl, Calico, and Purple Flash) had a minor foliar injury at EC of $7.4 \mathrm{dS} \cdot \mathrm{m}^{-1}$ when grown in a greenhouse with salt accumulation in the root zone. These results suggest that the degree of foliar damage depends on chile genotype. For landscape use, the shorter and compact appearance of ornamental chile is more aesthetically desirable and required less maintenance such as application of plant growth retardant (Azza Mazher et al., 2007; Fox et al., 2005). 
Table 1. Visual foliar salt damage ratings and leaf osmotic potential of 10 ornamental chile pepper cultivars irrigated with saline solution at electrical conductivity (EC) of 1.3 (control, nutrient solution), 4.1 , or $8.1 \mathrm{dS} \cdot \mathrm{m}^{-1}$ for 8 weeks $(\mathrm{n}=10)$.

\begin{tabular}{|c|c|c|c|c|c|}
\hline \multirow[b]{2}{*}{ Cultivars } & \multirow{2}{*}{$\frac{\text { Visual score }}{\text { EC } 8.1}$} & \multirow[b]{2}{*}{ Significance $P$ value ${ }^{z}$} & \multicolumn{3}{|c|}{ Osmotic potential (MPa) } \\
\hline & & & Control & EC 4.1 & EC 8.1 \\
\hline NuMex April Fool's Day & 5.0 & NS & $-1.80 \mathrm{a}^{\mathrm{y}}$ & $-1.72 \mathrm{a}$ & $-2.01 \mathrm{~b}$ \\
\hline NuMex Christmas & 4.7 & $<0.0001$ & $-1.58 \mathrm{a}$ & $-1.69 b$ & $-1.76 b$ \\
\hline NuMex Easter & 4.9 & 0.013 & $-1.83 \mathrm{a}$ & $-1.95 \mathrm{a}$ & $-1.88 \mathrm{a}$ \\
\hline NuMex Halloween & 4.9 & 0.0124 & $-1.20 \mathrm{a}$ & $-1.16 \mathrm{a}$ & $-0.99 \mathrm{a}$ \\
\hline NuMex Cinco de Mayo & 5 & NS & $-0.82 \mathrm{a}$ & $-0.98 \mathrm{a}$ & $-1.34 \mathrm{~b}$ \\
\hline NuMex Memorial Day & 2.5 & $<0.0001$ & $-1.35 \mathrm{a}$ & $-1.52 \mathrm{a}$ & $-1.89 b$ \\
\hline NuMex St. Patrick's Day & 4.9 & $<0.0001$ & $-1.49 \mathrm{a}$ & $-1.82 \mathrm{~b}$ & $-1.72 b$ \\
\hline NuMex Thanksgiving & 5 & NS & $-1.57 \mathrm{a}$ & $-1.78 b$ & $-2.03 \mathrm{c}$ \\
\hline NuMex Twilight & 5 & NS & $-1.64 \mathrm{a}$ & $-1.97 b$ & $-2.15 b$ \\
\hline NuMex Valentine's Day & 4.8 & $<0.0001$ & $-1.58 \mathrm{a}$ & $-1.71 \mathrm{~b}$ & $-1.90 \mathrm{c}$ \\
\hline
\end{tabular}

${ }^{\mathrm{z} P}$ values tested by PROC NPAR1WAY between control and EC 8.1. No foliar salt damage was observed on plants in EC 4.1 treatment.

${ }^{y}$ Means with the same small letters in the same row (among treatments) were not different tested by Student-Newman-Keuls multiple comparisons at $P=0.05$ NS $=$ nonsignificant.

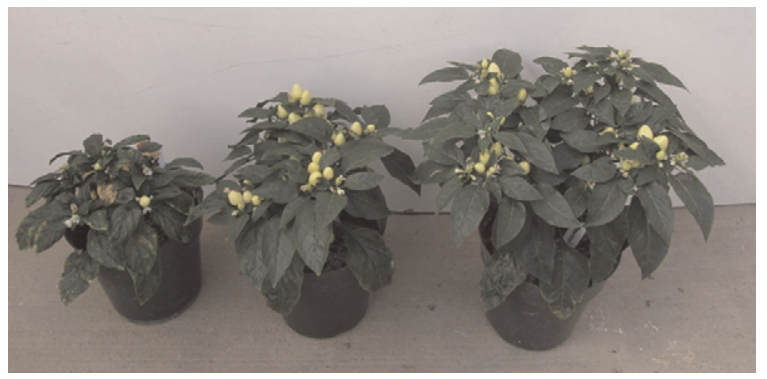

Fig. 1. 'NuMex Memorial Day' at the end of the experiment. From left to right, plants were in the EC 8.1, EC 4.1, and control treatments, respectively. Foliage salt damage is visible in EC 8.1 treatment. EC = electrical conductivity.

Elevated salinity decreased leaf $\psi_{\mathrm{S}}$ for most cultivars except 'NuMex Easter' and 'NuMex Halloween' (Table 1). The degree of reduction in leaf $\psi_{\mathrm{S}}$ varied among cultivars. 'NuMex Cinco de Mayo' had the highest, whereas 'NuMex Twilight' had the lowest

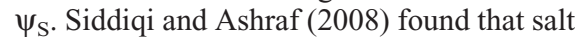
stress with $150 \mathrm{~mm}$ of $\mathrm{NaCl}$ significantly lowered the leaf water potential (more negative values) of 10 lines of safflower at the vegetative stage. Lowering $\psi_{\mathrm{S}}$ is one type of plant adaptation to salinity (Munns and Tester, 2008). Salinity often causes reduction in $\psi_{\mathrm{S}}$ of soil solution, and $\psi_{\mathrm{S}}$ becomes more negative with an increase in salinity of the rooting medium (Siddiqi and Ashraf, 2008).

Compared with the control, salinity solution at EC $4.1 \mathrm{dS} \cdot \mathrm{m}^{-1}$ slightly reduced the relative leaf, stem, fruit, and shoot DW of all cultivars except 'NuMex Cinco de Mayo', NuMex St. Patrick's Day', and 'NuMex Valentine's Day' (Table 2). Relative shoot DW of 'NuMex Christmas' and 'NuMex Memorial Day' was the lowest numerically and was statistically not different from that of 'NuMex April Fool's Day' and 'NuMex Twilight'. When plants were irrigated with saline solution at EC $8.1 \mathrm{dS} \cdot \mathrm{m}^{-1}$, shoot growth was greatly reduced, reflected in the low relative DW for all cultivars. 'NuMex Thanksgiving' had the highest relative shoot DW of $85 \%$, indicating a shoot DW reduction of $15 \%$ compared with that of the control. The lowest relative shoot DW for 'NuMex
Memorial Day' coincided with the lowest visual score (Table 1). 'NuMex Christmas' had the second lowest relative shoot DW, which again coincided with the second lowest visual score. The reduction of shoot DW varied with cultivars in EC of $8.1 \mathrm{dS} \cdot \mathrm{m}^{-1}$ treatment. Shoot DW of 'NuMex Memorial Day' was reduced by $74 \%$, the greatest reduction, compared with the control, 'NuMex Christmas', by $61 \%$, the second greatest reduction, 'NuMex St. Patrick's Day', by $48 \%$, 'NuMex Easter' by $46 \%$, and other cultivars by $40 \%$ or less. The leaf, stem, and shoot DW of 'NuMex Thanksgiving' and 'NuMex Twilight' decreased, but the fruit DW increased. These results were similar to previous reports on 'jalapeno' chile (Arrowsmith et al., 2012), in which chile plants treated with the highest salt level of $1.5 \% \mathrm{NaCl}$ produced fruit set more than twice that of control. Under a saltstressed condition, a strong physiological shift from vegetative to reproduction growth could be stimulated through allocating more photosynthate toward reproductive growth than vegetative growth (Van Zandt et al., 2003). The low visual scores were generally found in plants with larger shoot DW reduction. These results indicate that multiple parameters are helpful and necessary to accurately assess the relative salt tolerance of multiple genotypes.

Leaf mineral concentration. There were interactive effects of salinity treatment and cultivar on leaf ion concentrations. The concentrations of $\mathrm{Na}^{+}, \mathrm{K}^{+}, \mathrm{Ca}^{2+}, \mathrm{Mg}^{2+}, \mathrm{Cl}^{-}$,
$\mathrm{NO}_{3}{ }^{-}, \mathrm{PO}_{4}{ }^{3-}$, and $\mathrm{SO}_{4}{ }^{2-}$ in leaves varied with cultivars (Table 3 ). The $\mathrm{Na}^{+}$and $\mathrm{Cl}^{-}$concentrations increased significantly with increasing EC in all cultivars and the magnitude of increase varied with cultivar. The highest $\mathrm{Cl}^{-}$ concentration at EC 8.1 treatments was found in 'NuMex Memorial Day' with $64.8 \mathrm{mg} \cdot \mathrm{g}^{-1}$ DW, which was four times higher than the control and coincided with the lowest visual score and greatest shoot DW reduction. The highest $\mathrm{Na}^{+}$concentration of $10.9 \mathrm{mg} \cdot \mathrm{g}^{-1} \mathrm{DW}$ was observed in 'NuMex Christmas', coinciding with the second lowest visual score and second greatest shoot DW reduction. The lowest $\mathrm{Na}^{+}$concentrations were found in 'NuMex Thanksgiving' with lowest shoot DW reduction and 'NuMex Twilight' (one of the cultivars with low shoot DW reduction) and the lowest $\mathrm{Cl}^{-}$concentrations were in 'NuMex Thanksgiving'. Avoiding accumulation of $\mathrm{Na}^{+}$or $\mathrm{Cl}^{-}$in shoots is one of the mechanisms in plant adaptation to salinity (Munns and Tester, 2008). In this study, 'NuMex Thanksgiving' did not have any salt damage and had the smallest shoot DW reduction at the highest $\mathrm{EC}$ level, obviously as a result of its high ability to exclude $\mathrm{Cl}^{-}$ and $\mathrm{Na}^{+}$from accumulation in shoots.

$\mathrm{K}^{+}$concentrations decreased significantly with increasing EC in seven cultivars but not in 'NuMex April Fool's Day', 'NuMex St. Patrick's Day', or 'NuMex Valentine's Day'. The $\mathrm{K}^{+}$concentrations decreased $28 \%$ in 'NuMex Christmas'; $\approx 20 \%$ in 'NuMex Easter', 'NuMex Halloween', and 'NuMex Cinco de Mayo'; and $\approx 10 \%$ in 'NuMex Memorial Day', 'NuMex Thanksgiving', and 'NuMex Twilight'. Numerous studies with a wide range of horticulture crops have shown that $\mathrm{K}^{+}$concentration in plant tissue decreases as sodium salinity in the root media increases (Grattan and Grieve, 1999). However, other research has demonstrated that $\mathrm{K}^{+}$ may be preferentially acquired and transported against a strong $\mathrm{Na}^{+}$concentration gradient (Grattan and Grieve, 1999). In this study, the $\mathrm{K}^{+}$concentrations did not correlate with growth reduction or visual score.

$\mathrm{Mg}^{2+}$ concentrations decreased significantly with increasing EC in 'NuMex Christmas', 'NuMex St. Patrick's Day', 'NuMex Thanksgiving', and 'NuMex Twilight' but not in other cultivars. Salinity treatment affected leaf $\mathrm{Ca}^{2+}$ and $\mathrm{NO}_{3}{ }^{-}$concentration in all cultivars except for 'NuMex Thanksgiving'. $\mathrm{Ca}^{2+}$ concentrations increased with increasing EC. This was the result of the high $\mathrm{Ca}^{2+}$ concentrations in the solution because both $\mathrm{NaCl}$ and $\mathrm{CaCl}_{2}$ were added to the saline solution. $\mathrm{NO}_{3}{ }^{-}$concentrations decreased significantly with increasing EC. The salinity treatments did not affect shoot $\mathrm{SO}_{4}{ }^{2-}$ concentration in all cultivars except 'NuMex Halloween' and 'NuMex St. Patrick's Day', in which $\mathrm{SO}_{4}{ }^{2-}$ concentration was higher in the control than the other treatments. There was no significant difference in shoot $\mathrm{PO}_{4}{ }^{3-}$ concentration except 'NuMex Halloween' and 'NuMex Valentine's Day'.

Unlike drought, salt stress is associated with nutrient deficiency or ion imbalances, 
which affect physiological and biochemical responses related to plant development and growth (Kumar et al., 2008). $\mathrm{Cl}^{-}$accumulation in chile shoots affected negatively plant nutrient balance. Similar results were found in Casuarina equistifolia in which high levels of $\mathrm{Cl}^{-}$decreased $\mathrm{NO}_{3}{ }^{-}$absorption by plants, and phosphate uptake was inhibited by high concentrations of $\mathrm{NO}_{3}{ }^{-}$(Dutt et al., 1991). Nevertheless, the effect of salinity on plant tissue nutrient uptake differs among species and genotypes and salinity level. Generally, cultivars with smaller growth reduction and less salt damage at high salinity had lower $\mathrm{Na}^{+}$and/or $\mathrm{Cl}^{-}$concentrations. The concentrations of other ions did not have a correlation with growth reduction or salt damage. For long-term study for crops other than ornamental plants, mineral nutrition may affect final product quality and yield.

Seedling emergence of ornamental peppers. Germination substrate saturated with saline solution at EC $17.1 \mathrm{dS} \cdot \mathrm{m}^{-1}$ reduced germination and emergence percentages in most cultivars, reflected in relative emergence percentage and relative seedling emergence index of chile pepper (Table 4). The magnitude of reduction differed among cultivars. 'NuMex Halloween' had the highest relative emergence percent $(100 \%)$ followed by 'NuMex Cinco de Mayo' (94\%), 'NuMex Thanksgiving' (93\%), and 'NuMex Easter' $(81 \%)$. The smallest relative emergence percent was found in 'NuMex Christmas' (21\%) and 'NuMex Memorial Day' (39\%). In term of relative emergence index, 'NuMex Thanksgiving' had the highest values, while 'NuMex Christmas' and 'NuMex Memorial Day' had the lowest. These results indicated that 'NuMex Cinco de Mayo' and 'NuMex Thanksgiving' were the most tolerant cultivars, whereas 'NuMex Christmas' and 'NuMex Memorial Day' were the least tolerant ones. Zhani et al. (2012) reported that $\mathrm{NaCl}$ had a significant effect in germination percentage and time to germination, and $\mathrm{NaCl}$ at $8 \mathrm{~g} \cdot \mathrm{L}^{-1} \mathrm{de}-$ creased germination to $40 \%, 50 \%$, and $10 \%$ for Capsicum frutenses 'Awlad Haffouz', 'Korba', and 'Tebourba', respectively. Flynn et al. (2002) reported that salinity at or above $7 \mathrm{dS} \cdot \mathrm{m}^{-1}$ reduced chile pepper germination by $\approx 20 \%$.

Based on the seedling emergence, 'NuMex Christmas' and 'NuMex Memorial Day' performed equally worse than other cultivars. In the mature plant salt tolerance experiment, 'NuMex Christmas' in the EC of $8.1 \mathrm{dS} \cdot \mathrm{m}^{-1}$ treatment performed better than 'NuMex Memorial Day', although no substantial differences were found in the EC of $4.1 \mathrm{dS} \cdot \mathrm{m}^{-1}$ treatment between the two cultivars except stem DW. This may indicate that salt tolerance of 'NuMex Memorial Day' slightly decreased at high salinity in the mature plant stage or in other words, salt tolerance of 'NuMex Christmas' increased slightly at the mature plant stage. The best performers at the seedling emergence stage were 'NuMex Cinco de Mayo' and 'NuMex Thanksgiving', whereas in the mature plant stage, 'NuMex Thanksgiving' was slightly
Table 2. Relative dry weight (DW) of leaves, stems, fruits, and shoots of 10 ornamental chile pepper cultivars irrigated with saline solution at electrical conductivity (EC) of 1.3 (control, nutrient solution), 4.1 , or $8.1 \mathrm{dS} \cdot \mathrm{m}^{-1}$ for 8 weeks $(\mathrm{n}=10)$.

\begin{tabular}{|c|c|c|c|c|c|c|c|c|}
\hline \multirow[b]{2}{*}{ Cultivars } & \multicolumn{4}{|c|}{ Relative DW (\%) at EC 4.1} & \multicolumn{4}{|c|}{ Relative DW (\%) at EC 8.1} \\
\hline & Leaves & Stems & Fruits & Shoots & Leaves & Stems & Fruits & Shoots \\
\hline NuMex April Fool's Day & $80 c^{z}$ & $70 \mathrm{bc}$ & $82 \mathrm{bc}$ & $80 \mathrm{bcd}$ & $63 \mathrm{~cd}$ & $66 \mathrm{~b}$ & $63 \mathrm{c}$ & $63 \mathrm{bc}$ \\
\hline NuMex Christmas & $78 \mathrm{c}$ & $116 \mathrm{a}$ & $79 \mathrm{bc}$ & $65 \mathrm{~d}$ & 44 ef & $55 \mathrm{bc}$ & $56 \mathrm{c}$ & $39 \mathrm{~d}$ \\
\hline NuMex Easter & $86 \mathrm{bc}$ & $92 \mathrm{abc}$ & $95 \mathrm{bc}$ & $92 \mathrm{ab}$ & 57 cde & $54 \mathrm{bc}$ & $52 \mathrm{c}$ & $54 \mathrm{c}$ \\
\hline NuMex Halloween & $86 \mathrm{bc}$ & $84 \mathrm{abc}$ & $90 \mathrm{bc}$ & $88 \mathrm{abc}$ & $67 \mathrm{bc}$ & $71 \mathrm{~b}$ & $63 \mathrm{c}$ & $65 \mathrm{~b}$ \\
\hline NuMex Cinco de Mayo & $116 \mathrm{a}$ & $117 \mathrm{a}$ & $100 \mathrm{bc}$ & $106 \mathrm{a}$ & $80 \mathrm{~b}$ & $91 \mathrm{a}$ & $60 \mathrm{c}$ & $68 \mathrm{~b}$ \\
\hline NuMex Memorial Day & $72 \mathrm{c}$ & $63 \mathrm{c}$ & $67 \mathrm{c}$ & $68 \mathrm{~d}$ & $34 \mathrm{f}$ & $32 \mathrm{~d}$ & $20 \mathrm{~d}$ & $26 \mathrm{e}$ \\
\hline NuMex St. Patrick's Day & 94 bc & $90 \mathrm{abc}$ & $113 \mathrm{~b}$ & $103 \mathrm{a}$ & $51 \mathrm{de}$ & $43 \mathrm{~cd}$ & $56 \mathrm{c}$ & $52 \mathrm{c}$ \\
\hline NuMex Thanksgiving & $96 \mathrm{abc}$ & $91 \mathrm{abc}$ & $176 \mathrm{a}$ & $94 \mathrm{ab}$ & $105 \mathrm{a}$ & $67 \mathrm{~b}$ & $332 \mathrm{a}$ & $85 \mathrm{a}$ \\
\hline NuMex Twilight & $73 \mathrm{c}$ & $67 \mathrm{bc}$ & $90 \mathrm{bc}$ & $73 \mathrm{~cd}$ & $52 \mathrm{de}$ & $42 \mathrm{~cd}$ & $159 \mathrm{~b}$ & $63 \mathrm{bc}$ \\
\hline NuMex Valentine's Day & $108 \mathrm{ab}$ & $104 \mathrm{ab}$ & $102 \mathrm{bc}$ & $104 \mathrm{a}$ & $76 \mathrm{~b}$ & $65 \mathrm{~b}$ & $60 \mathrm{c}$ & $66 \mathrm{~b}$ \\
\hline
\end{tabular}

${ }^{\mathrm{z}}$ Means with the same small letters in the same column (among genotypes) were not different tested by Student-Newman-Keuls multiple comparisons at $P=0.05$.

Table 3. Shoot ion concentrations of 10 ornamental chile pepper cultivars irrigated with saline solution at electrical conductivity (EC) of 1.3 (control, nutrient solution), 4.1, or $8.1 \mathrm{dS} \cdot \mathrm{m}^{-1}$ for 8 weeks $(\mathrm{n}=10)$.

\begin{tabular}{|c|c|c|c|c|c|c|c|c|c|}
\hline \multirow[b]{2}{*}{ Cultivar } & \multirow[b]{2}{*}{ Treatment } & \multicolumn{8}{|c|}{ Ion concns $\left(\mathrm{mg} \cdot \mathrm{g}^{-1}\right)$} \\
\hline & & $\mathrm{Na}^{+}$ & $\mathrm{K}^{+}$ & $\mathrm{Ca}^{2+}$ & $\mathrm{Mg}^{2+}$ & $\mathrm{Cl}^{-}$ & $\mathrm{NO}_{3}^{-}$ & $\mathrm{PO}_{4}^{3-}$ & $\mathrm{SO}_{4}^{2-}$ \\
\hline$\overline{\text { NuMex }}$ & Control & $2.8 b^{z}$ & $56.0 \mathrm{a}$ & $17.1 \mathrm{c}$ & $8.1 \mathrm{a}$ & $10.2 \mathrm{~b}^{\mathrm{z}}$ & $9.7 \mathrm{a}$ & $5.6 \mathrm{a}$ & $7.3 \mathrm{a}$ \\
\hline \multirow[t]{2}{*}{ April Fool's Day } & EC 4.1 & $5.1 \mathrm{ab}$ & $63.1 \mathrm{a}$ & $22.0 \mathrm{~b}$ & $8.9 \mathrm{a}$ & $18.9 \mathrm{~b}$ & $4.3 \mathrm{~b}$ & $4.6 \mathrm{~b}$ & \\
\hline & EC 8.1 & $6.7 \mathrm{a}$ & $58.3 \mathrm{a}$ & $28.0 \mathrm{a}$ & $10.2 \mathrm{a}$ & $44.4 \mathrm{a}$ & $3.9 \mathrm{~b}$ & $5.1 \mathrm{ab}$ & \\
\hline \multirow[t]{3}{*}{ NuMex Christmas } & Control & $2.6 \mathrm{c}$ & $60.4 \mathrm{a}$ & $11.9 \mathrm{c}$ & $6.0 \mathrm{a}$ & $8.1 \mathrm{c}$ & $22.3 \mathrm{a}$ & $7.9 \mathrm{a}$ & \\
\hline & EC 4.1 & $5.1 \mathrm{~b}$ & $53.7 \mathrm{~b}$ & $14.4 \mathrm{~b}$ & $4.6 \mathrm{~b}$ & $18.3 \mathrm{~b}$ & $10.0 \mathrm{~b}$ & $7.2 \mathrm{a}$ & 4.5 \\
\hline & EC 8.1 & $10.9 \mathrm{a}$ & $43.2 \mathrm{c}$ & $17.5 \mathrm{a}$ & $4.4 \mathrm{~b}$ & $43.2 \mathrm{a}$ & $5.1 \mathrm{c}$ & $8.5 \mathrm{a}$ & \\
\hline \multirow[t]{3}{*}{ NuMex Easter } & Control & $2.6 \mathrm{~b}$ & $47.0 \mathrm{a}$ & $15.7 \mathrm{c}$ & $6.6 \mathrm{a}$ & $12.1 \mathrm{c}$ & $11.9 \mathrm{a}$ & $8.5 \mathrm{a}$ & 5.3 \\
\hline & EC 4.1 & $4.7 \mathrm{~b}$ & $42.9 \mathrm{~b}$ & $18.3 \mathrm{~b}$ & $5.6 \mathrm{~b}$ & $22.0 \mathrm{~b}$ & $6.5 \mathrm{~b}$ & $7.2 \mathrm{a}$ & \\
\hline & EC 8.1 & $4.7 \mathrm{a}$ & $37.7 \mathrm{c}$ & $21.1 \mathrm{a}$ & $6.3 \mathrm{a}$ & $40.2 \mathrm{a}$ & $2.4 \mathrm{c}$ & $7.4 \mathrm{a}$ & 7.2 \\
\hline \multirow[t]{3}{*}{ NuMex Halloween } & Control & $2.9 \mathrm{c}$ & $59.0 \mathrm{a}$ & $13.1 \mathrm{c}$ & $4.1 \mathrm{a}$ & $12.2 \mathrm{c}$ & $29.2 \mathrm{a}$ & $10.9 \mathrm{a}$ & \\
\hline & EC 4.1 & $3.6 \mathrm{~b}$ & $49.0 \mathrm{~b}$ & $15.7 \mathrm{~b}$ & $3.8 \mathrm{a}$ & $20.4 \mathrm{~b}$ & $8.3 \mathrm{~b}$ & $6.6 \mathrm{~b}$ & 4.0 \\
\hline & EC 8.1 & $7.3 \mathrm{a}$ & $46.9 \mathrm{~b}$ & $22.7 \mathrm{a}$ & $4.5 \mathrm{a}$ & $38.8 \mathrm{a}$ & $6.9 \mathrm{~b}$ & $7.6 \mathrm{~b}$ & 4.2 \\
\hline \multirow[t]{3}{*}{ NuMex Cinco de Mayo } & Control & $2.9 \mathrm{~b}$ & $58.2 \mathrm{a}$ & $15.9 \mathrm{~b}$ & $8.3 \mathrm{a}$ & $14.4 \mathrm{~b}$ & $15.0 \mathrm{a}$ & $4.7 \mathrm{a}$ & 5.4 \\
\hline & EC 4.1 & $3.1 \mathrm{~b}$ & $49.4 \mathrm{~b}$ & $17.4 \mathrm{~b}$ & $8.3 \mathrm{a}$ & $19.4 \mathrm{~b}$ & $5.8 \mathrm{~b}$ & $4.8 \mathrm{a}$ & 4.7 \\
\hline & EC 8.1 & $5.2 \mathrm{a}$ & $45.6 \mathrm{~b}$ & $22.4 \mathrm{a}$ & $9.2 \mathrm{a}$ & $45.1 \mathrm{a}$ & $3.9 \mathrm{~b}$ & $4.9 \mathrm{a}$ & 5.6 \\
\hline \multirow[t]{3}{*}{ NuMex Memorial Day } & Control & $1.5 \mathrm{c}$ & $58.8 \mathrm{a}$ & $10.6 \mathrm{~b}$ & $4.1 \mathrm{a}$ & $14.5 \mathrm{c}$ & $29.8 \mathrm{a}$ & $9.1 \mathrm{a}$ & 4.0 \\
\hline & EC 4.1 & $3.1 \mathrm{~b}$ & $56.6 \mathrm{a}$ & $14.8 \mathrm{a}$ & $4.5 \mathrm{a}$ & $41.1 \mathrm{~b}$ & $10.8 \mathrm{~b}$ & $8.3 \mathrm{a}$ & 4.7 \\
\hline & EC 8.1 & $5.3 \mathrm{a}$ & $52.1 \mathrm{~b}$ & $15.3 \mathrm{a}$ & $4.5 \mathrm{a}$ & $64.8 \mathrm{a}$ & $4.4 \mathrm{~b}$ & $8.5 \mathrm{a}$ & 4.5 \\
\hline \multirow[t]{3}{*}{ NuMex St. Patrick's Day } & Control & $3.3 \mathrm{~b}$ & $60.8 \mathrm{a}$ & $13.7 \mathrm{~b}$ & $4.9 \mathrm{a}$ & $10.3 \mathrm{c}$ & $23.4 \mathrm{a}$ & $8.6 \mathrm{a}$ & 7.0 \\
\hline & EC 4.1 & $3.0 \mathrm{~b}$ & $60.9 \mathrm{a}$ & $17.8 \mathrm{a}$ & $4.1 \mathrm{~b}$ & $23.3 \mathrm{~b}$ & $14.4 \mathrm{~b}$ & $7.6 \mathrm{a}$ & 4.0 \\
\hline & EC 8.1 & $7.3 \mathrm{a}$ & $48.6 \mathrm{a}$ & $18.7 \mathrm{a}$ & $3.3 \mathrm{c}$ & $39.0 \mathrm{a}$ & $4.9 \mathrm{c}$ & $4.9 \mathrm{a}$ & 3.5 \\
\hline \multirow[t]{3}{*}{ NuMex Thanksgiving } & Control & $0.6 \mathrm{~b}$ & $49.9 \mathrm{ab}$ & $12.9 \mathrm{a}$ & $6.8 \mathrm{a}$ & $6.9 \mathrm{a}$ & $22.8 \mathrm{a}$ & $4.7 \mathrm{a}$ & 4.1 \\
\hline & EC 4.1 & $0.9 \mathrm{~b}$ & $53.9 \mathrm{a}$ & $13.6 \mathrm{a}$ & $4.8 \mathrm{~b}$ & $15.1 \mathrm{a}$ & $19.3 \mathrm{a}$ & $4.4 \mathrm{a}$ & 3.5 \\
\hline & EC 8.1 & $2.7 \mathrm{a}$ & $43.2 \mathrm{~b}$ & $13.9 \mathrm{a}$ & $4.7 \mathrm{~b}$ & $10.0 \mathrm{a}$ & $16.0 \mathrm{a}$ & $3.8 \mathrm{a}$ & 3.1 \\
\hline \multirow[t]{3}{*}{ NuMex Twilight } & Control & $0.5 \mathrm{~b}$ & $49.9 \mathrm{a}$ & $13.4 \mathrm{~b}$ & $8.1 \mathrm{a}$ & $4.7 \mathrm{~b}$ & $13.4 \mathrm{a}$ & $4.6 \mathrm{a}$ & 4.8 \\
\hline & EC 4.1 & $0.9 \mathrm{ab}$ & $46.5 \mathrm{~b}$ & $12.3 \mathrm{~b}$ & $5.4 \mathrm{c}$ & $12.5 \mathrm{~b}$ & $8.9 \mathrm{~b}$ & $5.9 \mathrm{a}$ & 4.3 \\
\hline & EC 8.1 & $1.4 \mathrm{a}$ & $44.7 \mathrm{~b}$ & $18.1 \mathrm{a}$ & $7.1 \mathrm{~b}$ & $59.2 \mathrm{a}$ & $4.1 \mathrm{c}$ & $4.4 \mathrm{a}$ & 3.4 \\
\hline \multirow[t]{3}{*}{ NuMex Valentine's Day } & Control & $1.8 \mathrm{c}$ & $66.5 \mathrm{a}$ & $11.0 \mathrm{~b}$ & $3.7 \mathrm{a}$ & $8.5 \mathrm{c}$ & $14.8 \mathrm{a}$ & $7.3 \mathrm{a}$ & 5.2 \\
\hline & EC 4.1 & $4.8 \mathrm{~b}$ & $72.6 \mathrm{a}$ & $18.4 \mathrm{a}$ & $4.2 \mathrm{a}$ & $25.9 \mathrm{~b}$ & $10.1 \mathrm{~b}$ & $6.7 \mathrm{a}$ & $4.9 \mathrm{a}$ \\
\hline & EC 8.1 & $6.9 \mathrm{a}$ & $68.2 \mathrm{a}$ & $21.7 \mathrm{a}$ & $4.3 \mathrm{a}$ & $36.7 \mathrm{a}$ & $4.0 \mathrm{c}$ & $4.6 \mathrm{~b}$ & $4.3 \mathrm{a}$ \\
\hline
\end{tabular}

${ }^{\mathrm{z}}$ Means with the same small letters within cultivar were not different tested by Student-Newman-Keuls multiple comparisons at $P=0.05$.

Table 4. Relative seedling emergence percentage and relative emergence index of 10 ornamental chile pepper cultivars under non-saline or saline condition $(\mathrm{n}=3)$.

\begin{tabular}{lcc}
\hline Cultivar & $\begin{array}{c}\text { Relative } \\
\text { emergence }(\%)\end{array}$ & $\begin{array}{c}\text { Relative emergence } \\
\text { index }(\%)\end{array}$ \\
\hline NuMex April Fool's Day & $57 \mathrm{bcd}^{\mathrm{z}}$ & $22 \mathrm{bc}$ \\
NuMex Christmas & $21 \mathrm{~d}$ & $9 \mathrm{c}$ \\
NuMex Easter & $81 \mathrm{abc}$ & $39 \mathrm{bc}$ \\
NuMex Halloween & $100 \mathrm{a}$ & $48 \mathrm{~b}$ \\
NuMex Cinco de Mayo & $94 \mathrm{ab}$ & $70 \mathrm{a}$ \\
NuMex Memorial Day & $39 \mathrm{~cd}$ & $14 \mathrm{c}$ \\
NuMex St. Patrick's Day & $42 \mathrm{~cd}$ & $18 \mathrm{bc}$ \\
NuMex Thanksgiving & $93 \mathrm{ab}$ & $74 \mathrm{a}$ \\
NuMex Twilight & $68 \mathrm{abc}$ & $34 \mathrm{bc}$ \\
NuMex Valentine's Day & $53 \mathrm{bcd}$ & $24 \mathrm{bc}$ \\
\hline
\end{tabular}

${ }^{\mathrm{z}}$ Means with the same small letters within column were not different tested by Student-Newman-Keuls multiple comparisons at $P=0.05$. 
better than 'NuMex Cinco de Mayo' based on shoot DW. The second best performers in both seedling emergence and mature plant stages were basically the same: 'NuMex April Fool's Day', 'NuMex Easter', 'NuMex Halloween', 'NuMex Twilight', and 'NuMex Valentine's Day'. These results indicate that the order of relative salt tolerance among the 10 cultivars was generally the same in both experiments.

Plant response to salinity is often influenced by environmental conditions such as temperature, light intensity, and wind speed. Therefore, it is difficult to compare the salt tolerance among genotypes based on the salinity level (threshold) that leads to certain adverse responses. Nevertheless, salt tolerance can always be compared on a relative basis among genotypes and at different growth stages based on multiple parameters such as growth, visual quality, and $\mathrm{Na}^{+}$and $/ \mathrm{Cl}^{-}$accumulation in shoots.

In summary, 'NuMex Thanksgiving' was the most tolerant cultivar followed by 'NuMex Cinco de Mayo', whereas 'NuMex Memorial Day' was the least tolerant cultivar among the 10 with severe foliar damage at EC $8.1 \mathrm{dS} \cdot \mathrm{m}^{-1}$ and the greatest shoot growth reduction. 'NuMex Christmas' is the second least tolerant cultivar based on low seedling emergence and low visual score and shoot DW reduction at EC $8.1 \mathrm{dS} \cdot \mathrm{m}^{-1}$. All other eight cultivars were moderately tolerant and may be irrigated with saline solution at EC of up to $4.1 \mathrm{dS} \cdot \mathrm{m}^{-1}$ with little reduction in aesthetical values. The relative salt tolerance order among cultivars was generally consistent for both seedling emergence and mature plant growth stages.

\section{Literature Cited}

Arrowsmith, S., T.P. Egan, J.F. Meekins, D. Powers, and M. Metcalfe. 2012. Effects of salt stress on capsaicin content, growth, and fluorescence in a Jalapeño cultivar of Capsicum annuum (Solanaceae). BIOS 83:1-7.

Azza Mazher, A.M., E.M. Fatama El-Quesni, and M.M. Farahat. 2007. Responses of ornamental plants and woody tress to salinity. World Journal of Agricultural Sciences 3:386-395.

Coon, D., E. Votava, and P.W. Bosland. 2008. The chile cultivars of New Mexico State University. Agricultural Experiment Station. Bul. 763.

Dutt, S.K., A.R. Bal, and A.K. Bandyopadhyay. 1991. Salinity induced chemical changes in Casuarina equistifolia Forst. Egyptian Journal of Soil Science 31:57-63.

Flynn, R., R. Phillips, A. Ulery, R. Kochevar, L. Liess, and M. Villa. 2002. Chile seed germination as affected by temperature and salinity. Cooperative Extension Service, New Mexico State University, Las Cruces, NM.

Fox, L.J., J.N. Grose, B.L. Appleton, and S.J. Donohue. 2005. Evaluation of treated effluent as an irrigation source for landscape plants. J. Environ. Hort. 23:174-178.

Gavlak, R.G., D.A. Horneck, and R.O. Miller. 1994. Plant, soil, and water reference methods for the western region. Western Regional Extension Publication (WREP) 125.

Grattan, S.R. and C.M. Grieve. 1999. Salinitymineral nutrient relations in horticultural crops. Sci. Hort. 78:127-157.

Helmke, P.A. and D.L. Sparks. 1996. Lithium, sodium, potassium, rubidium, and cesium. In: Sparks, D.L. (ed.). Methods of soil analysis, Part 3, chemical methods. $5^{\text {th }}$ series. Soil Science Society of America and American Society of Agronomy, Madison, WI.

Kumar, V., V. Shriram, T.D. Nikam, N. Jawali, and M.G. Shitole. 2008. Sodium chloride-induced changes in mineral nutrients and proline accumulation in indica rice cultivars differing in salt tolerance. J. Plant Nutr. 31:1999-2017.

Maas, E.V. 1986. Salt tolerance of plants. Appl. Agr. Res. 1:12-26.

Marschner, H. 2002. Mineral nutrition of higher plants. 2nd Ed. Elsevier Academic Press, London, UK.

Munns, R. and M. Tester. 2008. Mechanisms of salinity tolerance. Annu. Rev. Plant Biol. 59: 651-681.
Niu, G. 2012. Salt tolerance of Capsicum species and genotypes, p. 150-164. In: Russo, V.M. (ed.). Peppers, botany, production and uses. CAB International, Wallingford, UK.

Niu, G. and D.S. Rodriguez. 2006. Relative salt tolerance of selected herbaceous perennials and groundcovers. Sci. Hort. 110:352-358.

Niu, G., D.S. Rodriguez, and T. Starman. 2010a. Response of bedding plants to saline water irrigation. HortScience 45:628-636.

Niu, G., D.S. Rodriguez, E. Call, P.W. Bosland, A. Ulery, and E. Acosta. 2010b. Responses of eight chile peppers to saline water irrigation. Sci. Hort. 126:215-222.

Niu, G., D.S. Rodriguez, R. Cabrera, J. Jifon, D. Leskovar, and K. Crosby. 2010c. Salinity and soil type effects on emergence and growth of pepper seedlings. HortScience 45:1265-1269.

Rhoades, J.D. 1999. Use of saline drainage water for irrigation, Agronomy Monograph No. 38. p. 615-657.

Rozema, J. and T. Flowers. 2008. Crops for a salinized world. Science 322:1478-1480.

Siddiqi, E.H. and M. Ashraf. 2008. Can leaf water relation parameters be used as selection criteria for salt tolerance in safflower (Carthamus tinctorius L). Pak. J. Bot. 40:221-228.

Stommel, J.R. and P.W. Bosland. 2005. Ornamental pepper, Capsicum annuum, p. 555-593. In: Anderson, N.O. (ed.). Flower breeding \& genetics: Issues, challenges, and opportunities for the 21st century. Kluwer Academic Publishers, The Netherlands.

Tabatabai, M.A. and W.T. Frankenberger, Jr. 1996. Liquid chromatography, p. 225-247. In: Sparks, D.L. (ed.). Methods of soil analysis, Part 3, chemical methods. $5^{\text {th }}$ series. Soil Science Society of America and American Society of Agronomy, Madison, WI.

Van Zandt, P.A., M.A. Tobler, E. Mouton, K.H Hasenstein, and S. Mopper. 2003. Positive and negative consequences of salinity stress for the growth and reproduction of the clonal plant, Iris hexagona. J. Ecol. 91:837-846.

Zhani, K., M.A. Elouer, H. Aloui, and C. Hannachi. 2012. Selection of a salt tolerant Tunisian cultivar of chile pepper (Capsicum frutescens). EurAsian Journal of Bioscience 6:47-59. 